\title{
Articulo \\ Telerehabilitación en el Paciente Oncológico
}

\section{Telerehabilitation in the Oncology Patient}

Autor Principal:

Dra. Vanessa Uclés Villalobos,

Médico especialista en Medicina Física y Rehabilitación.

Hospital Dr. Rafael Angel Calderón Guardia.

Dra. Gema Herrera Belmonte,

Médico especialista en Medicina Física y Rehabilitación.

Hospital Oncologico Caja Nacional de Salud La Paz - Bolivia.

Correspondencia a: gemaherrerabel@gmail.com

\section{Resumen}

Introducción: La telerehabilitación se refiere a la serie de procesos de diagnóstico y tratamiento a distancia y la entrega remota de diferentes servicios de rehabilitación por medio de tecnología en telecomunicación. Brinda múltiples beneficios en los pacientes oncológicos.

\section{Materiales y métodos}

Se realizó una revisión exhaustiva de la literatura mediante la búsqueda bibliográfica en las bases de datos de PubMed, Medline y EMBASE. Se estudiaron 86 artículos de los cuales 25 fueron los más relevantes.

\section{Resultados}

Se evidenciaron múltiples ventajes principalmente en relación a la funcionalidad, discapacidad, capacidad de ejercicio, perfil de actividad física, calidad de vida, fatiga, insomnio, dolor, ansiedad, depresión, prevenir hospitalizaciones, prevención secundaria. Algunas desventajas incluyen escepticismo, limitación en el examen físico, necesidad de habilidades tecnológicas, garantía de protección de confiabilidad, entre otras.

\section{Conclusiones}

La telerehabilitación es factible, realizable, práctica, aceptable, efectiva, segura tanto para los usuarios como profesionales de la salud. 
Responde a la necesidad de los servicios de salud de proveer cuidado de calidad, aumentando la accesibilidad y manteniendo o fomentando la continuidad del cuidado, especialmente para poblaciones vulnerables.

\section{Palabras Clave}

Telerehabilitación, telemedicina, rehabilitación oncológica

\section{Abstract}

Introduction: Telerehabilitation refers to the series of remote diagnosis and treatment processes and the remote delivery of different rehabilitation services through telecommunication technology. Provides multiple benefits in cancer patients.

\section{Materials and methods}

An exhaustive review of the literature was carried out by means of a bibliographic search in the databases of PubMed, Medline and EMBASE. 86 articles were studied of which 25 were the most relevant.

\section{Results}

Multiple advantages were evidenced mainly in relation to functionality, disability, exercise capacity, physical activity profile, quality of life, fatigue, insomnia, pain, anxiety, depression, preventing hospitalizations, secondary prevention. Some disadvantages include skepticism, limitation in physical examination, need for technological skills, guarantee of reliability protection, among others.

\section{Conclusions}

Telerehabilitation is feasible, practical, acceptable, effective, safe for both users and health professionals. It responds to the need for health services to provide quality care, increasing accessibility and maintaining or promoting continuity of care, especially for vulnerable populations.

\section{Keywords}

Telerehabilitation-Telemedicine- Oncological Rehabilitation.

\section{Introducción}

La discapacidad en América Latina es del 6 al $31 \%$ de la población, y sólo el $3 \%$ de los que requieren servicios de rehabilitación tienen acceso a ellos, según la Organización Mundial de la Salud.

La población con cáncer, tiene poco acceso a los servicios de rehabilitación (1) (2). El tratamiento de esta población debería tener como meta, además del tratamiento oncológico, el limitar la discapacidad (3). La discapacidad afecta al $40 \%$ de los pacientes con cáncer avanzado (4). Por lo tanto, deben ser considerados como parte de la rutina el cuidado continuo (2) y ser así una intervención proactiva que trate las causas de discapacidad (deficiencias físicas, dolor, inmovilidad) o discapacidad incipiente, y no una intervención reactiva, como usualmente es, cuando el paciente ha perdido catastróficamente su función y necesita cuidado institucional y generando altos costos (5) (4) (6) (7).

La telemedicina se documentó inicialmente en 1910 con el uso de redes telefónicas análogas para la transmisión de electrocardiogramas y electroencefalogramas y en el 1920 con el servicio de consulta médica para los salvavidas en clave morse, y con videoconferencias en 1959 (8). Con el mayor desarrollo desde la última década (9). La primera publicación sobre telerehabilitación se hace en 1998 (10).

Es importante recalcar que aún no existe un consenso sobre una estructura formal para dar el servicio de telerehabilitación. Es posible hacerlo tanto en el ambiente intrahospitalario como extrahospitalario (comunitario, domicilio), es decir, condiciones agudas y crónicas. Es útil para múltiples especialidades médicas y los 
respectivos padecimientos de los que se ocupan. Se documenta mucha heterogenicidad en cuanto a tipo de intervención, duración, frecuencia, medida de resultados (11) (8) (12) (13) (14) (15) (16) (17) (18) (19) (20) (21) (22).

La telerehabilitación tiene múltiples definiciones, entre las que cabe mencionar:

- Procesos de diagnóstico y tratamiento a distancia

- Entrega remota de diferentes servicios de rehabilitación por medio de tecnología en telecomunicación (23).

Durante la telerehabilitación es importante la interacción virtual entre el paciente y el clínico. Los entornos virtuales deben intentar simular los escenarios clínicos reales. Se considera preferible el uso de tecnologías sencillas como mensajes de voz, llamadas telefónicas, antes conocidas por teleasistencia (24). Y se está estudiando la factibilidad del uso de tecnologías/monitores personales comerciales (25).

Existen muchos recursos para la telerehabilitación, incluyendo tecnologías de telemonitoreo, realidad virtual, exoesqueletos rehabilitación basada en robots, consolas videojuegos, aplicaciones (App) (26).

Los servicios de telerehabilitación pueden incluir:

- Prevención

- Educación basada en evidencia

- Evaluación

- Consulta

- Apoyo/soporte

- Diagnóstico

- Definición de objetivos y metas

- Rehabilitación/terapia física, del lenguaje, ocupacional

- Prehabilitación

- Monitoreo/supervisión

- "Coaching"

- Asistencia para el regreso a casa (después de hospitalización) (23) (27) (17) (19) (28)

Y ser sincrónicos y/o asincrónicos (29).
En general, la telerehabilitación es bien aceptada por la población y además se sienten satisfechos con el servicio.

\section{Materiales y métodos}

Se realizó una revisión exhaustiva de la literatura mediante la búsqueda bibliográfica en las bases de datos de PubMed, Medline y EMBASE.

El criterio de búsqueda se fundamentó en los descriptores MeSH y DeCS: Telerehabilitation; Primary Health Care; Telemedicine Medical Informatics Applications; Oncological Rehabilitation. Se reunieron todos los artículos encontrados en una matriz bibliográfica de Excel. No se utilizaron filtros referentes al año de publicación, ni grupos etarios; se incluyeron artículos escritos en inglés y español.

Se reunieron 104 artículos en total y se eliminaron duplicados. El criterio de búsqueda y de selección se basó en los elementos PICO luego del análisis de contenido de cada uno: documentos realizados en humanos, con datos relevantes de telemedicina y telesalud orientados a la descripción epidemiológica, contexto social en pacientes oncológicos, necesidades del paciente y necesidades rehabilitación-telerrehabilitación.

El número final de estudios escogidos fue de 86 artículos para el grupo de trabajo de los cuales 25 fueron los más relevantes y se muestran a continuación. Se realizó el análisis en relación a determinar los siguientes aspectos: utilidad, ventajas, desventajas y barreras del uso de la Telerehabilitación en pacientes oncológicos.

Fuente: Elaboración propia 
Tabla 1: Resumen de los 25 articulos más relevantes

\begin{tabular}{|c|c|c|}
\hline Autor & & Titulo \\
\hline $\begin{array}{l}\text { N. } \\
\text { Castillo } \\
(2014)\end{array}$ & $\begin{array}{l}\text { Galiano- } \\
\text { et al. }\end{array}$ & $\begin{array}{l}\text { Agreement between } \\
\text { telerehabilitation } \\
\text { involving caregivers and } \\
\text { face-to-face clinical } \\
\text { assessment of } \\
\text { lymphedema in breast } \\
\text { cancer survivors }\end{array}$ \\
\hline $\begin{array}{l}\text { Laurelie } \\
\text { al.. (2015) }\end{array}$ & rwall et & $\begin{array}{l}\text { Examining user } \\
\text { perceptions of swallowit: } \\
\text { A pilot study of a new } \\
\text { telepractice application } \\
\text { For delivering intensive } \\
\text { swallowing therapy To } \\
\text { head and neck cancer } \\
\text { patients }\end{array}$ \\
\hline
\end{tabular}

Ana Bártolo et al. (2017)

Adele Krusche et al.. (2018)

Effectiveness of psychoeducational

interventions with telecommunication technologies on emotional distress and quality of life of adult cancer patients: a systematic review.

Renewed: protocol for a randomized controlled
Resultados

All outcome measures showed reliability estimates (a) $\geq 0.90$; the lowest reliability was obtained for the total volume on the non-affected side $(a=0.90)$. The diagnosis of lymphedema by the two methods also showed good inter-rater reliability $(\mathrm{Rho}=0.89)$. trial of a digital intervention to support quality of life in cancer survivors.
Insights were sought from 15 patients with oropharyngeal cancer who used SwallowiT to complete supported home swallowing therapy Perceptions were evaluated via structured questionnaires, completed following initial orientation to SwallowIT and on completion of CRT. Semistructured phone interviews were conducted 53 months post-treatment. The majority of patients reported positive initial perceptions towards SwallowIT for comfort (87\%), confidence (87\%), motivation (73\%) and support (87\%). No statistically significant change in perceptions was observed from baseline to end of CRT ( $p>0.05)$. Thematic analysis of interviews revealed four main themes: the ease of use of SwallowIT, motivating factors, circumstances which made therapy difficult, and personal preferences for service -delivery models.

Eight studies involving 1016 participants met inclusion criteria. The majority of the studies included $\left(n^{1 / 46}\right)$ used a randomized design and were published between 2007 and 2016. Interventions used a variety of delivery resources, such as telephone, e-mail and websites, but all were aiming to respond to information needs and develop stress control skills. A trend toward reducing distress and improving qol was found, but estimated effect sizes were typically small $(\mathrm{d}<0.5)$. Telephonically delivered psycho-educational interventions presented the highest between-group effects on these outcomes during survival, but were limited by sample size.

The primary outcome is quality of life measured by the European Organization for Research and Treatment of Cancer QLQ-c30. Secondary outcomes include anxiety and depression, fear of cancer recurrence, general wellbeing, enablement and items relating to costs for a health economics analysis.

\section{Conclusiones}

These preliminary

findings support the use of an internet-based system to assess lymphedema in breast cancer survivors, offering carers a useful role in helping patients to follow up this lifetime health problem.

These preliminary findings demonstrate that swallowit was wellperceived by the current group of HNC consumers and suggest that swallowit may be well-accepted as an alternate service-delivery model for delivering intensive Swallowing therapy during CRT.

The efficacy of
interventions using distance approaches in the cancer setting is still not wellestablished. Further research should be conducted through well-designed studies with more interactive features that minimize the lack of face-to-face interaction.

\section{Process}

measures

include perceptions of human support, intervention usage and satisfaction, and adherence to behavioural changes. Qualitative process evaluations will be conducted with patients and healthcare staff providing support. 


$\begin{array}{lll}\begin{array}{l}\text { Noelia Galiano- } \\ \text { Castillo et al. }\end{array} & \begin{array}{l}\text { Effect of an internet- } \\ \text { based telehealth system } \\ \text { (2017) }\end{array} & \\ & \\ & \text { and functional capacity } \\ & \text { cancer survivors: a } \\ & \text { secondary analysis of a } \\ & \text { randomized controlled } \\ & \text { trial }\end{array}$

Ciarán Haberlin et al. (2019)

Ehealth-based intervention to increase physical activity levels in people with cancer: protocol of a feasibility trial in an irish acute hospital setting

\begin{tabular}{|c|c|}
\hline $\begin{array}{l}\text { Tamara } \\
\text { Ownsworth et al. } \\
\text { (2019) }\end{array}$ & $\begin{array}{l}\text { Evaluation of a } \\
\text { telehealth psychological } \\
\text { support intervention for } \\
\text { people with primary } \\
\text { brain tumour and their } \\
\text { family members: study } \\
\text { protocol for a } \\
\text { randomised controlled } \\
\text { trial }\end{array}$ \\
\hline $\begin{array}{l}\text { Wilma Kuijpers et } \\
\text { al.. (2015) }\end{array}$ & $\begin{array}{l}\text { An interactive portal to } \\
\text { empower cancer } \\
\text { survivors: a qualitative } \\
\text { study on user } \\
\text { expectations }\end{array}$ \\
\hline
\end{tabular}

Noelia Galiano-

Castillo et al. (2013)
After intervention, the telerehabilitation group had significantly improved distances $(d=0.92, p<0.001)$ aswell as percentage of predicted of the 6-min walk test $(d=0.93, p<0.001)$ compared with the control group. Significant improvement was also observed favoring the telerehabilitation group for the number of consonants recalled in total compared with the control group $(d=0.47, p=0.04)$. These findings were maintained after 6-month follow-up $(\mathrm{d}=0.80, \mathrm{p}=$ $0.001 ; \mathrm{d}=0.76, \mathrm{p}=0.002$; and $\mathrm{d}=0.57, \mathrm{p}=0.02$ respectively). Analysis was based on intention-totreat principle.
These findings support the effectiveness of a telehealth system based on an 8-week physical exercise to achieve improvements and maintain them after 6month follow-up in terms of functional and cognitive performance in breast cancer survivors. This broad-reach modality could help the growing number of cancer survivors to face their disabling side effects.

Primary outcomes will be feasibility measures related to the study (recruitment capability, data collection procedures, adherence and compliance,

Evaluation of the resources to implement the study and evaluation of participant responses to the intervention).

Secondary measures will evaluate preliminary efficacy of the intervention in terms of clinical outcomes (body composition, pa (objective and self-report), quality of life and aerobic capacity). Primary and secondary outcomes will be assessed at baseline (as appropriate), at conclusion of the intervention and at a 6-month followup.

Results will indicate whether the tele-mast program is associated with better clinical outcomes and is more cost-effective than existing cancer support services. Such outcomes will contribute to effective and accessible psychosocial care for the brain tumour population.

Important themes included fulfillment of information This is the first study that needs, communication, motivation, quality of evaluated the feedback, and supervision. Cancer survivors were expectations of cancer primarily interested in features that could fulfill their survivors and health information needs: scp, access to their emr, and an professionals concerning overview of appointments. Health professionals an interactive portal. considered pros and telemonitoring as most useful Both groups were features, as these provide relevant information about positive about the survivors' health status.we recommend to minimally introduction of such a include these features in an interactive portal for portal, although their cancer survivors.

preferences for the various features differed. These findings reflect their unique perspective and emphasize the importance of involving multiple stakeholders in the actual design process.

Technological support using telerehabilitation systems is a promising strategy with great advantage of a quick and efficient contact with the health professional. It is not known the role of telerehabilitation through therapeutic exercise as a support tool to implement an active lifestyle which has been shown as an effective resource to improve fitness and reduce musculoskeletal disorders of these women. 
J.G. Timmerman

et al. (2017)
Mario Lozano et al.. (2016)

Josien G. Timmerman et al.. (2016)
Andrea Albergoni et al.. (2019)

Ambulant monitoring
and web-accessible
home-based exercise
program during
outpatient follow-up for
resected lung cancer
survivors: actual use and
feasibility in clinical
practice
practice
Integral strategy to supportive care in breast cancer survivors through occupational therapy and a m-health system: design of a randomized clinical trial

co-creation of an ictsupported cancer rehabilitation application for resected lung cancer survivors: design and evaluation
Seventeen olc patients (age (sd): 59 (8) years; 8

female) actively used the modules. S\&pam use varied from 1 to 11 monitoring days prior to outpatient consultations. Patients used wep most frequently during the first 5 weeks, wth an average of four logins a week. Fifty-eight percent used wep beyond 7 weeks. No adverse situations occurred, and patients felt confident using the applications.

Perceived added value included active lifestyle promotion, decreased anxiety, and accessibility to specialized hcps. Physiotherapists used wep as intended.

Contrarily, physicians scarcely used information from s\&pam. To promote future adoption, strategies should focus on high-level patient tailoring of the technology, and formalization of including the applications in the clinical workflow.

This study has been designed to seek to address the new needs for support and treatment of breast cancer survivors, reflecting the emerging need to merge new low cost treatment options with much-needed involvement of health professionals in this type of patients.

The developed application consists of: 1) selfmonitoring of symptoms and physical activity using on-body sensors and a smartphone, and 2) a web based physical exercise program. $71 \%$ of Ic patients and $78 \%$ of hcps were willing to use the application as part of lung cancer treatment. Accessibility of data via electronic patient records was essential for hcps. Lc patients regarded a positive attitude of the hcp towards the application essential. Overall, the usability (sus median score $=70$, range $35-95$ ) was rated acceptable.

The role of technology in adherence to physical activity programs in patients with Chronic diseases experiencing fatigue: a Systematic review
Ambulant monitoring and web-accessible home exercise is clinically feasible for olc patients. However, low level of adoption by referring physicians may hamper successful implementation. tool to further improve
The search resulted in 1790 hits; finally, eight studies were included, with a total number of 205 patients. Study quality was moderate except for one study of high quality. Only three disease types emerged, copd, $\mathrm{hf}$, and cancer. Pa programs were rather short (from 8 to 13 weeks) except for one 3-year-long study. Five studies employed pedometers and two an activity monitor. Three studies based their adherence on steps, the remaining studies focused on active minutes. Adherence was explicitly reported in two studies, and otherwise derived. Four studies showed high adherence levels (85\% week-10, 89\% week-8, $81 \%$ week-13, 105\% week-13, 83\% average week-112 ) and three low levels (56\% week- $12,41 \%$ year- 2 , 14 year-3).
A telehealthcare application that facilitates symptom monitoring and physical fitness training is considered a useful recovery following surgery of resected lung cancer (Ic) patients. Involvement of end users in the design process appears to be necessary to optimize chances of adoption, compliance and implementation of telemedicine.

The small number of studies identified did not allow to stablish whether the use of monitoring technology could improve adherence to pa programs in patients with chronic diseases experiencing fatigue, but the current evidence seems to suggest that this is a field warranting further study, particularly into how monitoring technology can help to engage patients to adhere to pa programs. 
Gill Hubbard et

al.. (2018)
Physical activity referra to cardiac rehabilitation, leisure centre or telephonedelivered consultations in postsurgical people with breast cancer: a mixed methods process evaluation
In phase i, 30\% ( $n=20)$ of eligible patients ( $n=20$ ) consented, $85 \%(n=17)$ chose referral to leisure centre, and $15 \%(n=3)$ chose cardiac rehabilitation. In phase ii, 32\% ( $n=12)$ consented, $25 \%(n=3)$ chose leisure centre and $75 \%(n=9)$ chose telephone-delivered pa consultations. Walking at light intensity for about an hour was the most common pa. All phase i participants received an induction by a cardiac rehabilitation physiotherapist or pa specialist from the leisure centre but only $50 \%$ of phase ii participants received an induction by a pa specialist from the leisure centre. Four themes were identified from qualitative interviews about programme choice: concerns about physical appearance, travel distance, willingness to socialise and flexibility in relation to doing pa. Four themes were identified about facilitators and barriers for engaging in pa: feeling better, feeling ill, weight management, family and friends.

Neale R

Chumbler, phd et

al. (2012)

Effects of telerehabilitation on physical function and disability for stroke patients a randomized, controlled trial

Community-based

Francesco

Benvenuti et al. (2014) exercise for upper limb paresis: a controlled trial with telerehabilitation
The current communitybased pa intervention is not yet suitable for a definitive effectiveness randomized controlled trial. Further work is needed to optimise pr programme reach, pa dose and intervention fidelity
The 2 complementary primary outcomes (late-life function and disability instrument function and telephone version of functional independence measure) improved at 6 months for the steler group and declined for the usual care group, but the differences were not statistically significant ( $\mathrm{p} 0.25$, late-life function and disability instrument; p0.316). Several of secondary outcomes were statistically significant. At 6 months, compared with the usual care group, the steler group showed statistically significant improvements in 4 of the 5 late-life function and disability instrument disability component subscales (p0.05), and approached significance in 1 of the 3 function component subscales (p0.06).

Compared with the control group, patients in the experimental group demonstrated significant gains in arm function as measured by the wolf motor function test, 9-hole peg test, motricity index, and nottingham extended activities of daily living questionnaire. The intervention received high satisfaction ratings and produced no adverse events. Only 30\% of the subjects attended kiosks regularly. Outcomes for this group did not differ significantly from those who only practiced at home.
The steler intervention significantly improved physical function, with improvements persisting up to 3 months after completing the intervention. Steler could be a useful supplement to traditional poststroke rehabilitation given the limited resources available for in-home rehabilitation for stroke survivors.

Home- and communitybased exercise for arm paresis is safe and effective.

Telerehabilitation interventions will need additional enhancements to improve effectiveness. The optimal upper extremity exercise prescription poststroke remains to be established.

While telerehabilitation shows promise in patients with cardiopulmonary diseases, compelling evidence is still limited. There is a need for more detailed, high quality studies and for studies on the use of videobased telerehabilitation. events reported in telerehabilitation compared with center-based exercise.

Participants in this study reported high visual clarity and ease-of-use, but provided suggestions for further improvements in group-based video telerehabilitation for HF. (1) perspectives of a heart failure Telerehabilitation program: A mixed methods approach

Rita Hwang et al Cost-utility analysis of (2019)

home-based telerehabilitation compared with centrebased rehabilitation in patients with heart failure
Heart failure telerehabilitation appears to be less costly and as effective for the health care provider as traditional centre-based rehabilitation 


$\begin{array}{lll}\begin{array}{l}\text { Laurence } \\ \text { Wilson et al. }\end{array} & \begin{array}{l}\text { Recent directions in } \\ \text { telemedicine: review of } \\ \text { (2015) }\end{array} \\ & \begin{array}{l}\text { trends in research and } \\ \text { practice }\end{array}\end{array}$

Agostini Michaela et al. (2015)

Muhammad S Beg, et al. (2017)
Goris Hung et al (2019)

Effects telerehabilitation in Occupational therapy practice: A systematic review

Bena cartmill et al (2016)
Computer literacy and health locus of control as determinants for readiness and acceptability telepractice in a head and neck cancer populatior

Telerehabilitation and recovery of motor function: a systematic review and metaanalysis
It is concluded that two major drivers of contemporary tele medicine development are a high volume demand for a particular clinical service, and/or a high criticality of need for clinical expertise to deliver the service. These areas offer promise for further study and enhancement of applicable telemedicine methods and have the potential for large-scale deployments internationally, which would contribute significantly to the advancement of healthcare

Telerehabilitation offers an alternative service delivery model for occupational therapy, not only bridging Distance but also offering user-friendly treatment for patients at home. Further research, particularly on the use of the Most cuttingedge mobile technology, is needed to determine effectiveness in occupational therapy practice treating Various diseases, conditions and impairments and the characteristics of patients, interventions and therapists that lead to The best fit with this alternative and emerging form of service delivery.

Head/neck cancer HNC patients have high computer literacy and an internal health locus of control, both are positive factors to support telepractice models of care. This may include asynchronous models requiring heightened capacity for self-management.
Twelve studies were included involving different populations (i.e. neurological, total knee arthroplasty (TKA), cardiac) of patients. Inconclusive finding were found on the effect of telerehabilitation for neurological patients (SMD1/40.08, Cl 95\%1/4=0.13, 0.29), while both for cardiac (SMD1/40.24, Cl 95\%1/40.04, 0.43) and TKA patients (Timed Up and

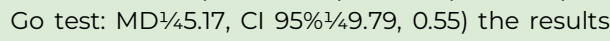
were in favour of telerehabilitation.
Conclusive evidence on the efficacy of telerehabilitation for treatment of motor function, regardless of pathology, was not reached. Nevertheless, a strong positive effect was found for patients following orthopaedic surgery, suggesting that the increased intensity provided by telerehabilitation is a promising option to be offered to patients. More and higher quality research is needed in this field especially with neurological patients.

Commercially available physical activity monitors provide clinicians an opportunity to obtain oncology patient health measures to an unprecedented degree. These devices can provide objective and quantifiable measures of physical activity, which are not subject to errors or bias of self-reporting or shorter duration of formal testing. Priorworkonso-called quantified-self datawasbasedonolder-generation, research-grade accelerometers, which

laid the foundation for consumer-based physical activity monitoring devices to be validated as a feasible and reliable tool in patients with cancer. Physical activity monitors are being used in chronic conditions including chronic obstructive pulmonary disease, congestive heart failure, diabetes mellitus, and obesity. Differing demographics, compounded with higher symptom and treatment burdens in patients with cancer, imply that additional work is needed to understand the unique strengths and weaknesses of physical activity monitors in this population. Oncology programs can systematically implement these tools into their workflows in an adaptable and iterative manner. Translating large amounts of data collected from an individual physical activity monitoring device into clinically relevant information requires sophisticated data compilation and reduction. In this article,wesummarize the characteristics of older- and newer-generation physical activity monitors, review the validation of physical activity monitors with respect to health-related quality-of-life assessments, and describe the current role of these devices for the practicing oncologist. We also highlight the challenges and next steps needed for physical activity monitors to provide relevant information that can change the current state of oncology practice. 


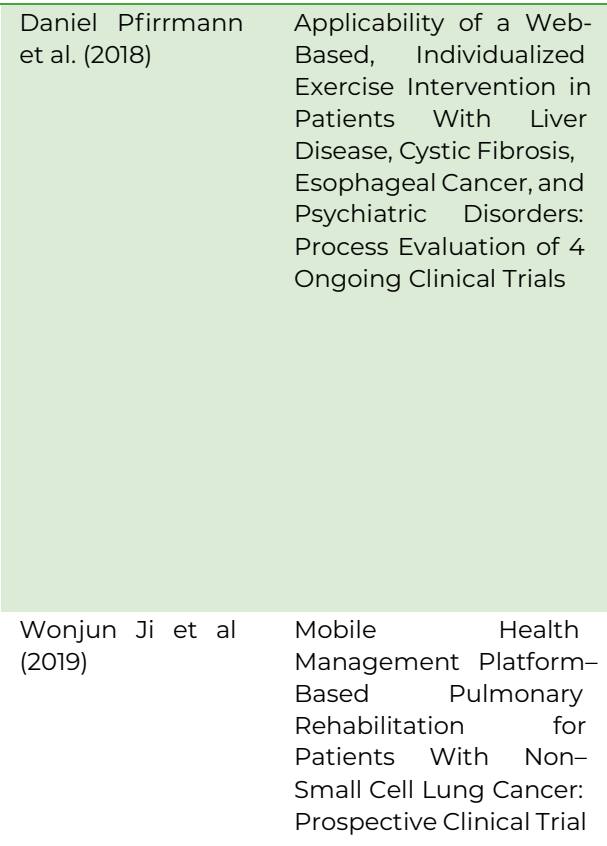

Fuente: Elaboración propia
A total of 20 participants (5 from each trial) were analyzed. During the intervention period, a regular contact and a consequent implementation of exercise prescription were easily achieved in all substudies. Across the 4 substudies, there was a significant decrease in log-in rates $(\mathrm{P}<.001)$ and log-in durations $(\mathrm{P}<.001)$ over time. A detailed view of the different studies shows a significant decrease in log-in rates and log-in durations in the HELP study $(P=.004$; $\mathrm{P}=.002)$ and iPEP study ( $\mathrm{P}=.02 ; \mathrm{P}=.001)$, whereas the EXDEP study $(P=.58 ; P=.38)$ and COMMED study $(P=.87 ; P=.56)$ showed no significant change over the 8-week intervention period. There was no significant change in physical activity within all studies $(P=.31)$. Only in the HELP study, the physical activity level increased steadily over the period analyzed $(P=.045)$. Overall, 17 participants $(85 \%, 17 / 20)$ felt secure and were not scared of injury, with no major differences in the subtrials.

Patients used the newly developed mobile health pulmonary rehabilitation app and a real-time patient monitoring website. In all participants, significant changes were observed in 6MWD at 12 weeks from a mean of $433.43 \mathrm{~m}$ (SD 65.60) to

471.25m (SD 75.69; $P=.001$ ), and $M M R C$ from a mean score of 0.94 (0.66) to 0.61 (SD 0.82; P=.02). The intervention significantly improved their quality of life (EuroQol-visual analog scale [EQ-VAS]) compared with baseline (mean score 76.05, SD 12.37 vs 82.09 , SD 13.67, respectively; $\mathrm{P}=.002$ ).
The universal use of the Web-based intervention appears to be applicable across the heterogonous collectives of our study patients with regard to age and disease. Although the development of physical activity shows only moderate improvements, flexible communication and tailored support could be easily integrated into patients daily routine.

A personalized mobile health-based pulmonary rehabilitation app for recording and monitoring real-time health data of patients with non-small cell lung cancer can supplement traditional health care centerbased rehabilitation programs.

This technology can encourage improvement of physical activity, dyspnea, and quality of life. 


\section{Resultados}

Los principales hallazgos encontrados en relación a los aspectos que se consideraron al realizar la revisión sistemática de los artículos incluidos son los siguientes:

Se ha documentado la utilidad de la telerehabilitación en el paciente oncológico en aspectos como:

- Funcionalidad

- Discapacidad

- Capacidad de ejercicio

- Perfil de actividad física

- Calidad de vida

- Fatiga

- Insomnio

- Dolor

- Ansiedad, depresión

- Prevenir hospitalizaciones

- Prevención secundaria (14) (39) (41) (17) (42).

Sus usos también son para la mejoría de:

- Funcionamiento físico

- Movilidad

- Funcionalidad/capacidad funcional

- Fuerza muscular

- Función cognitiva

- Estrés

- Depresión

- Apoyo psicológico

- Estilos de vida saludables / actividad física-dieta saludable

- Independencia

- Composición corporal/disminución de peso

- Dolor

- Fatiga

- Calidad de vida

- Adherencia

- Costos

- Estadías hospitalarias

- Accesibilidad

- Motivación

- Monitoreo

- Prehabilitación

- Terapia (física, ocupacional, del lenguaje)

- Necesidades de cuidados posagudos/post egreso hospitalario (43) (44) (45) (5) (46) (47) (48) (49) (50) (51) (52) (24) (1) (53) (54) (55) (56).
En general, se mejoran los resultados clínicos (6). Ofrece también a los cuidadores un rol útil en el seguimiento de los pacientes, involucrándose en las evaluaciones (57). Y también pueden ser apoyados psicológicamente junto con sus familiares (56).

En resumen:

- Procesos asistenciales: teleconsulta

- Apoyo a la continuidad asistencial: transmisión, información de analítica, historia digital compartida, etc.

- Información a usuarios: acceso a documentos, buscadores, web, consultoría electrónica, etc.

- Formación de profesionales: bases documentales (guías de práctica clínica o $\mathrm{MBE}$ ), trabajo colaborativo en investigación, trabajo en grupo (videoconferencia, coordinación de tareas, revisiones cruzadas o sesiones clínicas virtuales), simulación virtual, etc (58).

$\mathrm{Al}$ paciente le interesa informarse sobre el diagnóstico, tratamiento, seguimiento, mantenerse comunicado con sus pares y con el personal de salud, logrando retroalimentación de calidad, programas individualizados de rehabilitación y automanejo psicosocial (59) (60) (61).

Las ventajas de la telerehabilitación son múltiples, como:

-aceptación del paciente y profesionales de la salud (con o sin terapia convencional asociada) -responde a las demandas/necesidades por la alta incidencia de adultos mayores, discapacidad, entre otros

- Disminuye costos

- Es personalizable, según metas específicas

- Disminución de listas de espera y de consultas

- Disminución de estancias hospitalarias (facilita) egreso hospitalario más temprano provee al paciente y cuidados educación y apoyo - Accesibilidad/disminuye brechas, geográficas, escenarios y a los diferentes profesionales y especialistas de salud-recursos del cuidado de la salud 
- Comodidad

- Motivación

- Adherencia

- Efectividad

- Seguimiento a largo plazo

- Aumenta dosis de terapia sin supervisión entrenamiento más intensivo

- Posibilidad de monitorización (biométricas, síntomas)

- (Alta) satisfacción del paciente y profesionales de la salud

- Promueve el autocuidado

- Adaptabilidad / flexibilidad de escenarios, horarios, herramientas-disminución de "burnout" - Posibilidad de integrar mejor las habilidades aprendidas en la vida diaria (11) $(11,23)(62)$ (63) (16) (17) (18) (64) (19) (20) (9) (65) (28)

Las cuales quisiera resumir como "provee el cuidado adecuado, en el lugar y momento adecuado" (9).

\section{Las desventajas descritas son:}

- Escepticismo del paciente para interactuar remotamente con los profesionales de la salud (10)

- Limitaciones en la evaluación del paciente/examen físico (requiere de apoyo y educación del paciente y/o red de apoyo) (39) (66) (28), y el examen físico debe ser modificado (15)

Para lo cual existe el recurso de los "telepresentadores", que son asistentes en los encuentros de telemedicina (pueden ser médicos generales, enfermeras, etc) (9).

- Se requieren ciertas habilidades tecnológicas y/o capacitación-entrenamiento adicional (del paciente y/o personal de salud) (27) (16)

- Políticas y regulaciones (9)

- Garantía de la protección de la confidencialidad / privacidad (66)

Las cuales en su mayoría son subsanables. 
Tabla 2: Resumen ventajas y desventajas modificado de (58) (27) (67) (8):

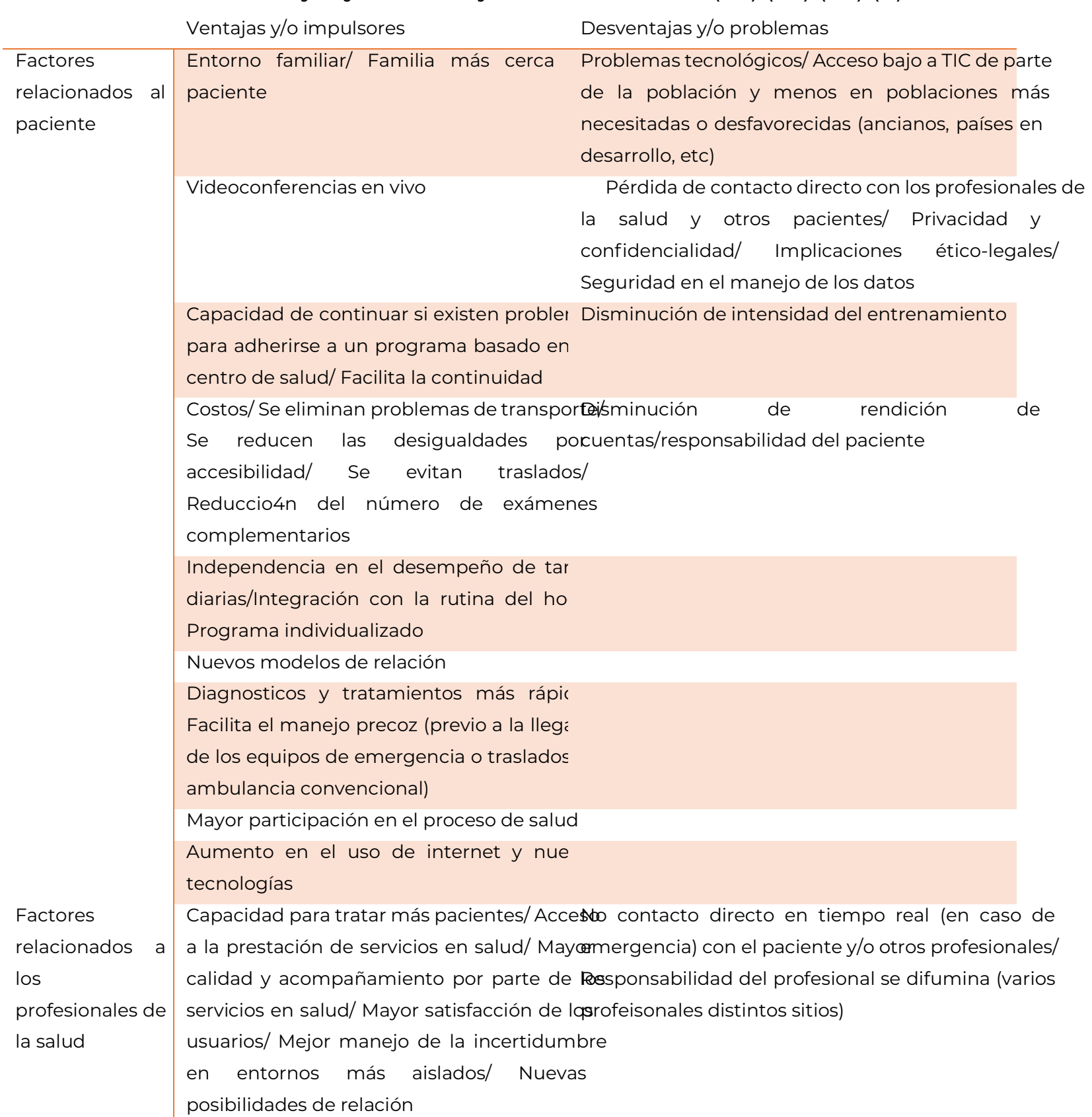

posibilidades de relación

Capacidad de combinar con telemonitore Clases educativas más difíciles vía telefónica 


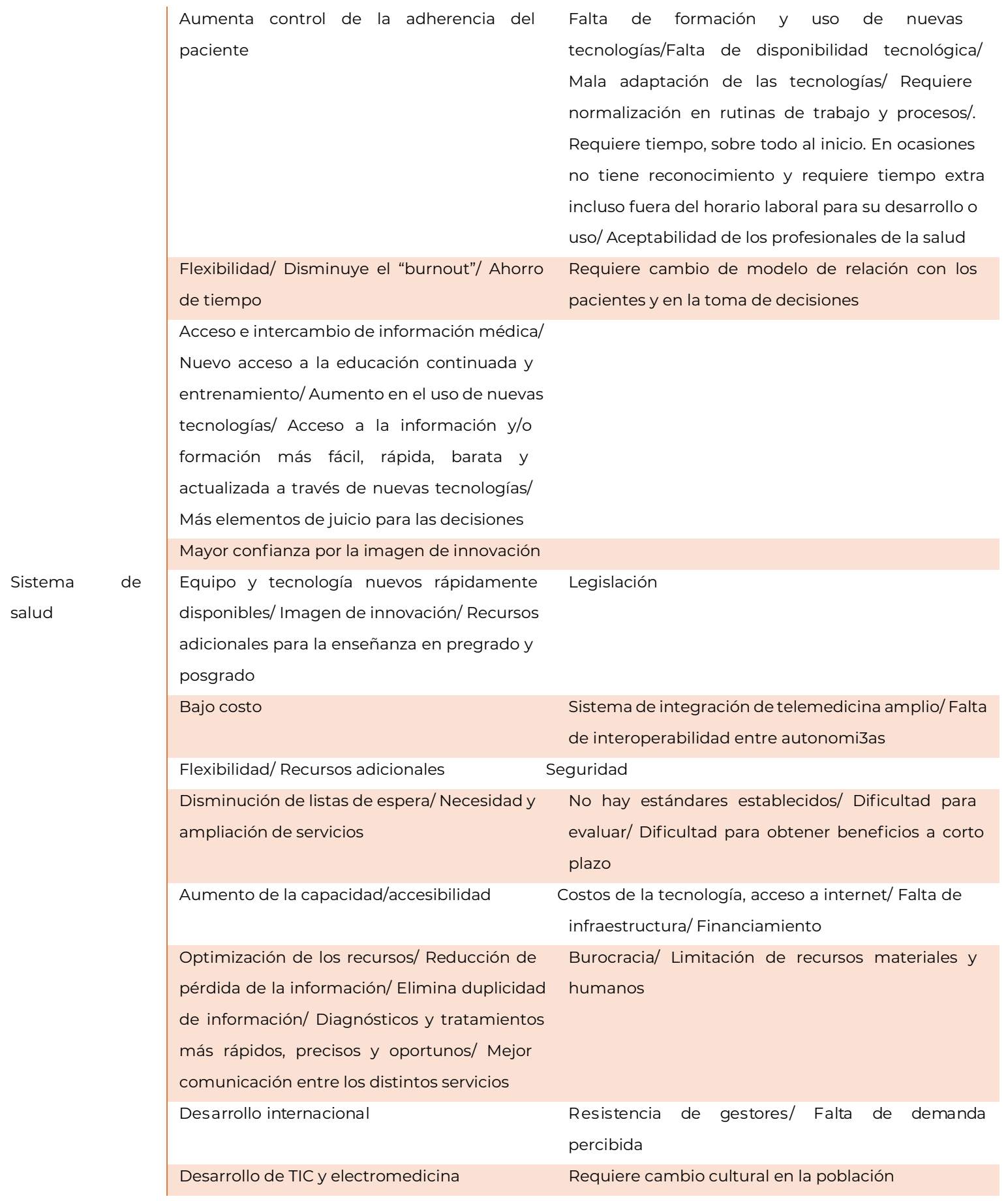

Fuente: Elaboración propia 


\section{Discusión}

La telerehabilitación parece ser un modelo alternativo más efectivo o de similar efectividad que la atención de rehabilitación tradicional. El nivel de evidencia que existe para la telerehabilitación es de bajo a moderado. Además es menos costosa pero se desconoce el costo-efectividad. No se reportan efectos adversos (30) (31) (32) (33) (34) (35) (36) (37) (38) (28) (39). Sin embargo, siempre se reconoce su potencialidad (14) (39) (17).

"El potencial de las TIC en salud ha sido identificado en 8 dimensiones de contribución han sido identificadas: acceso, eficacia, eficiencia, calidad, seguridad, generación de conocimiento, impacto en la economía e integración. Cada una de ellas se vincula a los diferentes ámbitos de aplicación: prevención, diagnóstico, tratamiento, monitoreo, educación sanitaria, gestión de los servicios y comercio electrónico en el sector salud. Los beneficios y externalidades positivas se extienden tanto a los pacientes y ciudadanos en general, como a los profesionales de salud y al conjunto de la sociedad por sus efectos en términos de crecimiento económico" (40).

Es muy importante involucrar a los usuarios/pacientes en que realicen retroalimentación para satisfacer mejor sus necesidades y mejorar los servicios, así como la colaboración y el trabajo en equipo entre los profesionales de la salud, idealmente interdisciplinario (8) (68) (26) (10).

También se deben tomar consideraciones para la seguridad de su uso como ser:

- Estratificar el riesgo del paciente para recibir rehabilitación

- Contraindicaciones para el entrenamiento con ejercicio

- Sesiones iniciales educativas

- Indicaciones individualizadas

- Consentimiento informado

- Aceptación y motivación para participar
- Red de apoyo-el paciente debe estar acompañado, idealmente si es durante el ejercicio además capacitado para dar primeros auxilios y llamar a servicios de salud en caso de emergencia (68) (27).

Una barrera significativa, que hay que subsanar es la baja adopción de esta estrategia por parte de médicos referidores (69), también la falta de información sobre el servicio y el equipo disponible, la falta de experiencia y confianza usando el equipo, el estigma del uso del equipo y los inconvenientes usando el equipo (70).

Estas barreras pueden minimizarse mediante:

- Educación/ promoción/ facilitación/ motivación/ empoderamiento.

- Protocolización/ estandarización/ automatización (67)

Especialmente la educación al usuario, promoviendo una actitud positiva hacia el equipo. Utilizar equipo que sea fácil de usar y confiable y que satisface las necesidades del paciente (70).

- Existencia de protocolos que se adapten al contexto.

- Necesidad de formación previa.

-Visión de futuro e innovadora.

- Normalización del programa en el sistema organizativo.

- Necesidad de mantener la equidad para clínicos y usuarios.

- Compromiso de las personas involucradas.

- Desarrollo tecnológico.

- Apoyo económico e institucional/ Apoyo de la administración (generalizando los proyectos de telemedicina) (58).

La OMS indica que los componentes que contribuyen a la implementación de Salud digital son:

1) Contenido de salud: información alineada con prácticas recomendadas de salud o contenido de salud validado.

2) Intervenciones de salud digital: tecnología digital para alcanzar objetivos del sector salud. 
3) Aplicaciones digitales: sistemas de tecnologías de información y comunicación y canales de comunicación que facilitan la entrega de intervenciones digitales y contenido de salud (71).

Finalmente, las modalidades de telemedicina y telerehabilitación podrían promover un acceso a servicios de salud más equitativo, independiente de las limitaciones físicas, sociales, económicas del paciente y de sus familiares; logrando así mayor apego a los tratamientos indicados, facilidad de seguimiento, mejor calidad de atención y potencial reducción de costos tanto para el paciente como para el sistema de salud. Estos aspectos son especialmente relevantes en pacientes, como los pacientes oncológicos, que, por la naturaleza de la enfermedad de base, tienden a estar confinados en su casa, o muchas veces habitan en regiones lejanas al acceso de algunos servicios de atención más especializados, por lo que la implementación correcta de este tipo de telerehabilitación resultaría especialmente beneficiosa en este grupo poblacional.

\section{Conclusiones}

La telerehabilitación es una opción para satisfacer la alta demanda de los servicios de rehabilitación de los diagnósticos más prevalentes y que inciden de forma significativa en las listas de espera de muchas de estas unidades en las diferentes entidades hospitalarias e institutos oncológicos, de forma efectiva, eficaz, segura y accesible. Lo cual puede significar el ahorro de recursos, traslados, pero especialmente tiempo.

Ofrece un escenario de trabajo cómodo y que garantizaría la atención continua incluso en casos de emergencia, tanto para el paciente como para el colaborador.

En conclusión, la telerehabilitación es factible, realizable, práctica, aceptable, efectiva, segura, y la mayoría, tanto para los usuarios como profesionales de la salud, preferirían un modelo combinado de atención complementaria: "cara a cara” y telerehabilitación (12) (72) (63) (16) (73) (74) (71). Responde a la necesidad de los servicios de salud de proveer cuidado de calidad, aumentando la accesibilidad y manteniendo o fomentando la continuidad del cuidado, especialmente para poblaciones vulnerables, así como es una estrategia que potencialmente ahorre tiempo y costos (económicos y sociales), es decir, sostenible (75) (30) (74) (65) (21). Mejora la entrega de cuidado de la salud en un amplio rango de aplicaciones y de forma segura y satisfactoria, cuyo mayor beneficio es el acceso (22). Por lo tanto, provee una manera útil de disminuir las inequidades y fortalece los servicios de salud (75). Sin embargo, no es una solución universal, debe individaulizarse $\mathrm{y}$ adaptarse (68).

Para conseguir resultados de un servicio de telesalud se debe establecer una red colaborativa, cubrir las necesidades reales, utilizar tecnologías simples, tener al menos algunos componentes presenciales y ser viable económicamente (costo-efectivo) (76) (77) (78) (71). Lo más difícil son las cuestiones organizativas/administrativas, sin descuidar el marco social, que deben considerarse al introducir nuevas tecnologías (79).

El éxito va a depender de la planificación y evaluación sistemática, idealmente antes de su implementación (80) (8).

Es una intervención/herramienta innovadora beneficiosa, que ayuda a optimizar eficiencia de los servicios de salud, de gran potencial, reproducible, aplicable universalmente, a tiempo, componente viable-factible, efectiva, para el cuidado integral con mejorías modestas (44) (5) (81) (46) (47) (48) (60) (82) (83) (24) (1) (6) (7) (56) (57). Preferiblemente como complemento/suplemento o en su defecto alternativo a la atención presencial (59) (61). Y que se acople a las percepciones y necesidades de los usuarios, involucrándolos desde el diseño 
para la optimización de las oportunidades de adopción, cumplimiento e implementación (84) (85) (86). Con un abordaje interdisciplinario (49).

\section{Conflicto de intereses}

Los autores declaran no tener conflicto de intereses

\section{Bibliografía}

1. Cheville AL, Moynihan T, Herrin J, Loprinzi C, Kroenke K. Effect of Collaborative Telerehabilitation on Functional Impairment and Pain Among Patients With Advanced-Stage Cancer: A Randomized Clinical Trial. JAMA Oncol. 2019 May 1;5(5):644-652.

2. Zhao J, Mao Z, Fedewa SA, Nogueira L, Yabroff KR, Jemal A, et al. The Affordable Care Act and access to care across the cancer control continuum: A review at 10 years. CA Cancer J Clin. 2020 Mar 23;

3. Cheville AL, Kollasch J, Vandenberg J, Shen T, Grothey A, Gamble G, et al. A home-based exercise program to improve function, fatigue, and sleep quality in patients with Stage IV lung and colorectal cancer: a randomized controlled trial. J Pain Symptom Manage. 2013 May; 45(5) : 811-821.

4. Cheville AL, Moynihan T, Basford JR, Nyman JA, Tuma ML, Macken DA, et al. The rationale, design, and methods of a randomized, controlled trial to evaluate the effectiveness of collaborative telecare in preserving function among patients with late stage cancer and hematologic conditions. Contemp Clin Trials. 2018;64:254-264.
5. Galiano-Castillo N, Cantarero-Villanueva I, Fernández-Lao C, Ariza-García A, Díaz-Rodríguez L, Del-Moral-Ávila R, et al. Telehealth system: A randomized controlled trial evaluating the impact of an internet-based exercise intervention on quality of life, pain, muscle strength, and fatigue in breast cancer survivors. Cancer. 2016 Oct 15;122(20):3166-3174.

6. Patel MI. Collaborative Telerehabilitation-A Smart Move for Patients With Advanced Cancer. JAMA Oncol. 2019 May 1;5(5):652-653.

7. Longacre CF, Nyman JA, Visscher SL, Borah BJ, Cheville AL. Cost-effectiveness of the Collaborative Care to Preserve Performance in Cancer (COPE) trial tele-rehabilitation interventions for patients with advanced cancers. Cancer Med. 2020 Apr;9(8):2723-2731.

8. IBÁÑEZ C, CADENA Á, ZEA RÉS. Telemedicine: Introduction, application and principles of development.

9. Scholten J, Poorman C, Culver L, Webster JB. Department of Veterans Affairs Polytrauma Telerehabilitation: Twenty-First Century Care. Phys Med Rehabil Clin N Am. 2019;30(1):207-215.

10. Peretti A, Amenta F, Tayebati SK, Nittari G, Mahdi SS. Telerehabilitation: Review of the State-of-the-Art and Areas of Application. JMIR Rehabil Assist Technol. 2017 Jul 21;4(2):e7.

11. Stroetmann K, Kubitschke L. How can telehealth help in the provision of integrated care?

12. Piron L, Turolla A, Agostini M, Zucconi C, Cortese F, Zampolini M, et al. Exercises for paretic upper limb after stroke: a combined virtual-reality and telemedicine approach. J Rehabil Med. 2009 Nov;41(12):1016-1102. 
13. Wilson LS, Maeder AJ. Recent directions in telemedicine: review of trends in research and practice. Healthc Inform Res. 2015 Oct 31;21(4):213-222.

14. Reeder B, Chung J, Stevens-Lapsley J. Current telerehabilitation research with older adults at home: an integrative review. J Gerontol Nurs. 2016 Oct 1;42(10):15-20.

15. Tenforde AS, Hefner JE, Kodish-Wachs JE, Iaccarino MA, Paganoni S. Telehealth in physical medicine and rehabilitation: A narrative review. PM R. 2017 May;9(5S):S51-S58.

16. Hwang R, Mandrusiak A, Morris NR, Peters R, Korczyk D, Bruning J, et al. Exploring patient experiences and perspectives of a heart failure telerehabilitation program: A mixed methods approach. Heart Lung. 2017 Apr 17;46(4):320-327.

17. van Egmond MA, van der Schaaf M, Vredeveld T, Vollenbroek-Hutten MMR, van Berge Henegouwen MI, Klinkenbijl JHG, et al. Effectiveness of physiotherapy with telerehabilitation in surgical patients: a systematic review and meta-analysis. Physiotherapy. 2018 Jun 19;104 (3): 277-298.

18. Howard IM, Kaufman MS. Telehealth applications for outpatients with neuromuscular or musculoskeletal disorders. Muscle Nerve. 2018 Apr 17;58(4):475-485.

19. Galea MD. Telemedicine in Rehabilitation. Phys Med Rehabil Clin N Am. 2019 Mar 5;30(2):473-483.

20. Ramey L, Osborne C, Kasitinon D, Juengst S. Apps and mobile health technology in rehabilitation: the good, the bad, and the unknown. Phys Med Rehabil Clin N Am. 2019 Mar 5;30(2):485-497.
21. Haulman A, Geronimo A, Chahwala A, Simmons Z. The Use of Telehealth to Enhance Care in ALS and other Neuromuscular Disorders. Muscle Nerve. 2020 Jun;61(6):682-691.

22. Tanaka MJ, Oh LS, Martin SD, Berkson EM. Telemedicine in the Era of COVID-19: The Virtual Orthopaedic Examination. J Bone Joint Surg Am. 2020 Apr 24;

23. Agostini M, Moja L, Banzi R, Pistotti V, Tonin P, Venneri A, et al. Telerehabilitation and recovery of motor function: a systematic review and meta-analysis. J Telemed Telecare. 2015 Jun;21(4):202-213.

24. Fillon M. Patients with advanced-stage cancer may benefit from telerehabilitation. CA Cancer J Clin. 2019 Jul 18;69(5):349-350.

25. Gupta A, Stewart T, Bhulani N, Dong Y, Rahimi Z, Crane K, et al. Feasibility of wearable physical activity monitors in patients with cancer. JCO Clin Cancer Inform. 2018;2:1-10.

26. Matthew-Maich N, Harris L, Ploeg J, Markle-Reid M, Valaitis R, Ibrahim S, et al. Designing, implementing, and evaluating mobile health technologies for managing chronic conditions in older adults: A scoping review. JMIR Mhealth Uhealth. 2016 Jun 9;4(2):e29.

27. Piotrowicz E, Piepoli MF, Jaarsma T, Lambrinou E, Coats AJS, Schmid J-P, et al. Telerehabilitation in heart failure patients: The evidence and the pitfalls. Int J Cardiol. 2016 Oct 1;220:408-413.

28. Laver KE, Adey-Wakeling Z, Crotty M, Lannin NA, George S, Sherrington C. Telerehabilitation services for stroke. Cochrane Database Syst Rev. 2020 Jan 31;1:CD010255. 
29. Hung Kn G, Fong KN. Effects of telerehabilitation in occupational therapy practice: A systematic review. Hong Kong J Occup Ther. 2019 Jun;32(1):3-21.

30. Kairy D, Lehoux P, Vincent C, Visintin M. A systematic review of clinical outcomes, clinical process, healthcare utilization and costs associated with telerehabilitation. Disabil Rehabil. 2009;31(6):427-447.

31. Hwang R, Bruning J, Morris N, Mandrusiak A, Russell T. A systematic review of the effects of telerehabilitation in patients with cardiopulmonary diseases. J Cardiopulm Rehabil Prev. 2015 Dec;35(6):380-389.

32. Moffet H, Tousignant M, Nadeau S, Mérette $\mathrm{C}$, Boissy $\mathrm{P}$, Corriveau $\mathrm{H}$, et al. In-Home Telerehabilitation Compared with Face-to-Face Rehabilitation After Total Knee Arthroplasty: A Noninferiority Randomized Controlled Trial. J Bone Joint Surg Am. 2015 Jul 15;97(14):1129-1141.

33. Cottrell MA, Galea OA, O'Leary SP, Hill AJ, Russell TG. Real-time telerehabilitation for the treatment of musculoskeletal conditions is effective and comparable to standard practice: a systematic review and meta-analysis. Clin Rehabil. 2017 May;31(5):625-638.

34. Pastora-Bernal JM, Martín-Valero R, Barón-López FJ, Guerrero Moyano N, Estebanez-Pérez M-J. Telerehabilitation after arthroscopic subacromial decompression is effective and not inferior to standard practice: Preliminary results. J Telemed Telecare. 2017 Jan 1;1357633X17706583.

35. Jiang S, Xiang J, Gao X, Guo K, Liu B. The comparison of telerehabilitation and face-to-face rehabilitation after total knee arthroplasty: A systematic review and meta-analysis. J Telemed Telecare. 2018 May;24(4):257-262.
36. Chen J, Liu M, Sun D, Jin Y, Wang T, Ren C. Effectiveness and neural mechanisms of home-based telerehabilitation in patients with stroke based on fMRI and DTI: A study protocol for a randomized controlled trial. Medicine. 2018 Jan;97(3):e9605.

37. Hwang R, Morris NR, Mandrusiak A, Bruning J, Peters R, Korczyk D, et al. Cost-Utility Analysis of Home-Based Telerehabilitation Compared With Centre-Based Rehabilitation in Patients With Heart Failure. Heart Lung Circ. 2019 Dec;28(12):1795-1803.

38. Grona SL, Bath B, Busch A, Rotter T, Trask C, Harrison E. Use of videoconferencing for physical therapy in people with musculoskeletal conditions: A systematic review. J Telemed Telecare. 2018 Jun;24(5):341-355.

39. Khan F, Amatya B, Kesselring J, Galea M. Telerehabilitation for persons with multiple sclerosis. Cochrane Database Syst Rev. 2015 Apr 9;(4):CD010508.

40. Las TIC en algunos de los retos del sector salud.

41. Dodakian L, McKenzie AL, Le V, See J, Pearson-Fuhrhop K, Burke Quinlan E, et al. A Home-Based Telerehabilitation Program for Patients With Stroke. Neurorehabil Neural Repair. 2017 Nov;31(10-11):923-933.

42. Bernocchi P, Vitacca M, La Rovere MT, Volterrani M, Galli T, Baratti D, et al. Home-based telerehabilitation in older patients with chronic obstructive pulmonary disease and heart failure: a randomised controlled trial. Age Ageing. 2018 Jan 1;47(1):82-88.

43. Head BA, Studts JL, Bumpous JM, Gregg JL, Wilson L, Keeney C, et al. Development of a telehealth intervention for head and neck cancer patients. Telemed J E Health. 2009 Jan;15(1):44-52. 
44. Faett BL, Brienza DM, Geyer MJ, Hoffman LA. Teaching self-management skills in persons with chronic lower limb swelling and limited mobility: evidence for usability of telerehabilitation. Int J Telerehabil. 2013 Jun 11;5(1):17-26.

45. Lyons KD, Hull JG, Kaufman PA, Li Z, Seville JL, Ahles TA, et al. Development and initial evaluation of a telephone-delivered, behavioral activation, and problem-solving treatment program to address functional goals of breast cancer survivors. J Psychosoc Oncol. 2015 Feb 10;33(2):199-218.

46. Galiano-Castillo N, Arroyo-Morales M, Lozano-Lozano M, Fernández-Lao C, Martín-Martín L, Del-Moral-Ávila R, et al. Effect of an Internet-based telehealth system on functional capacity and cognition in breast cancer survivors: a secondary analysis of a randomized controlled trial. Support Care Cancer. 2017 Jun 22;25(11):3551-3559.

47. Ward EC, Wall LR, Burns CL, Cartmill B, Hill AJ. Application of telepractice for head and neck cancer management: a review of speech language pathology service models. Curr Opin Otolaryngol Head Neck Surg. 2017 Jun;25(3):169-174.

48. Wall LR, Ward EC, Cartmill B, Hill AJ, Porceddu SV. Examining user perceptions of SwallowIT: A pilot study of a new telepractice application for delivering intensive swallowing therapy to head and neck cancer patients. J Telemed Telecare. 2017 Jan;23(1):53-59.

49. Lozano-Lozano M, Martín-Martín L, Galiano-Castillo N, Álvarez-Salvago F, Cantarero-Villanueva I, Fernández-Lao C, et al. Integral strategy to supportive care in breast cancer survivors through occupational therapy and a m-health system: design of a randomized clinical trial. BMC Med Inform Decis Mak. 2016 Nov 25;16(1):150.

50. Beg MS, Gupta A, Stewart T, Rethorst CD. Promise of wearable physical activity monitors in oncology practice. J Oncol Pract. 2017;13(2):82-89.

51.van der Linden SD, Sitskoorn MM, Rutten G-JM, Gehring K. Feasibility of the evidence-based cognitive telerehabilitation program Remind for patients with primary brain tumors. J Neurooncol. 2018 May;137(3):523-532.

52. Krusche A, Bradbury K, Corbett T, Barnett J, Stuart B, Yao GL, et al. Renewed: Protocol for a randomised controlled trial of a digital intervention to support quality of life in cancer survivors. BMJ Open. 2019 Mar 1;9(3):e024862.

53. Carlson LE, Subnis UB, Piedalue K-AL, Vallerand J, Speca M, Lupichuk S, et al. The ONE-MIND Study: Rationale and protocol for assessing the effects of ONlinE MINDfulness-based cancer recovery for the prevention of fatigue and other common side effects during chemotherapy. Eur J Cancer Care (Engl). 2019 Jul;28(4):e13074.

54. Bártolo A, Pacheco E, Rodrigues F, Pereira A, Monteiro S, Santos IM. Effectiveness of psycho-educational interventions with telecommunication technologies on emotional distress and quality of life of adult cancer patients: a systematic review. Disabil Rehabil. 2019;41(8):870-878.

55. Haberlin C, Broderick J, Guinan EM, Darker C, Hussey J, O'Donnell DM. eHealth-based intervention to increase physical activity levels in people with cancer: protocol of a feasibility trial in an Irish acute hospital setting. BMJ Open. 2019 Mar 8;9(3):e024999. 
56. Ownsworth T, Chambers S, Aitken JF, Foote M, Pinkham MB, Gordon LG, et al. Evaluation of a telehealth psychological support intervention for people with primary brain tumour and their family members: Study protocol for a randomised controlled trial. Eur J Cancer Care (Engl). 2019 Jul 10;28(4):e13132.

57. Galiano-Castillo N, Ariza-García A, Cantarero-Villanueva I, Fernández-Lao C, Sánchez-Salado C, Arroyo-Morales M. Agreement between telerehabilitation involving caregivers and face-to-face clinical assessment of lymphedema in breast cancer survivors. Support Care Cancer. 2014 Jan;22(1):253-258.

58. Prados Castillejo JA. Telemedicina, una herramienta también para el médico de familia. Atención Primaria. 2013 Mar;45(3):129-132.

59. Kuijpers W, Groen WG, Loos R, Oldenburg HSA, Wouters MWJM, Aaronson NK, et al. An interactive portal to empower cancer survivors: a qualitative study on user expectations. Support Care Cancer. 2015 Sep;23(9):2535-2542.

60. Pfirrmann D, Haller N, Huber Y, Jung P, Lieb K, Gockel I, et al. Applicability of a Web-Based, Individualized Exercise Intervention in Patients With Liver Disease, Cystic Fibrosis, Esophageal Cancer, and Psychiatric Disorders: Process Evaluation of 4 Ongoing Clinical Trials. JMIR Res Protoc. 2018 May 22;7(5):e106.

61. Ji W, Kwon H, Lee S, Kim S, Hong JS, Park YR, et al. Mobile Health Management Platform-Based Pulmonary Rehabilitation for Patients With Non-Small Cell Lung Cancer: Prospective Clinical Trial. JMIR Mhealth Uhealth. 2019 Jun 21;7(6):e12645.
62. Shukla H, Nair SR, Thakker D. Role of telerehabilitation in patients following total knee arthroplasty: Evidence from a systematic literature review and meta-analysis. J Telemed Telecare. 2017 Feb;23(2):339-346.

63. Shulver W, Killington M, Morris C, Crotty M. Well, if the kids can do it, I can do it": older rehabilitation patients" experiences of telerehabilitation. Health Expect. 2017;20(1):120-129.

64. Sarah S, Wolfgang M-B, Claudia P. Effect of telerehabilitation on long-term adherence to yoga as an antihypertensive lifestyle intervention: Results of a randomized controlled trial. Complement Ther Clin Pract. 2019 May;35:148-153.

65. Paganoni S, van de Rijn M, Drake K, Burke K, Doyle M, Ellrodt AS, et al. Adjusted cost analysis of video televisits for the care of people with amyotrophic lateral sclerosis. Muscle Nerve. 2019 Jun 27;60(2):147-154.

66. Boccalandro EA, Dallari G, Mannucci PM. Telemedicine and telerehabilitation: current and forthcoming applications in haemophilia. Blood Transfus. 2019 Feb 4;17(5):385-390.

67. Thomas RJ, Beatty AL, Beckie TM, Brewer LC, Brown TM, Forman DE, et al. Home-Based Cardiac Rehabilitation: a scientific statement from the american association of cardiovascular and pulmonary rehabilitation, the american heart association, and the american college of cardiology. J Cardiopulm Rehabil Prev. 2019;39(4):208-225.

68. Mort M, Roberts C, Pols J, Domenech M, Moser I, EFORTT investigators. Ethical implications of home telecare for older people: a framework derived from a multisited participative study. Health Expect. 2015 Jun;18(3):438-449. 
69. Timmerman JG, Dekker-van Weering MGH, Stuiver MM, Groen WG, Wouters MWJM, Tönis TM, et al. Ambulant monitoring and web-accessible home-based exercise program during outpatient follow-up for resected lung cancer survivors: actual use and feasibility in clinical practice. J Cancer Surviv. 2017 Dec;11(6):720-731.

70. Cook EJ, Randhawa G, Sharp C, Ali N, Guppy A, Barton G, et al. Exploring the factors that influence the decision to adopt and engage with an integrated assistive telehealth and telecare service in Cambridgeshire, UK: a nested qualitative study of patient "users" and "non-users". BMC Health Serv Res. 2016 Apr 19;16:137.

71. WHO guideline Recommendations on Digital Interventions for Health System Strengthening. Geneva: World Health Organization; 2019.

72. Chumbler NR, Quigley P, Li X, Morey M, Rose D, Sanford J, et al. Effects of telerehabilitation on physical function and disability for stroke patients: a randomized, controlled trial. Stroke. 2012 Aug;43(8):2168-2174.

73. Edgar MC, Monsees S, Rhebergen J, Waring J, Van der Star T, Eng JJ, et al. Telerehabilitation in Stroke Recovery: A Survey on Access and Willingness to Use Low-Cost Consumer Technologies. Telemed J E Health. 2017;23(5):421-429.

74. Kouskoukis M-N, Botsaris C. Cost-Benefit Analysis of Telemedicine Systems/Units in Greek Remote Areas. PharmacoEconomics Open. 2017 Jun;1(2):117-121.

75. Wootton R, Geissbuhler A, Jethwani K, Kovarik C, Person DA, Vladzymyrskyy A, et al. Long-running telemedicine networks delivering humanitarian services: experience, performance and scientific output. Bull World Health Organ. 2012 May 1;90(5):341-347D.
76. Alkmim MB, Figueira RM, Marcolino MS, Cardoso CS, Pena de Abreu M, Cunha LR, et al. Improving patient access to specialized health care: the Telehealth Network of Minas Gerais, Brazil. Bull World Health Organ. 2012 May 1;90(5):373-378.

77. Lewis T, Synowiec C, Lagomarsino G, Schweitzer J. E-health in low- and middle-income countries: findings from the Center for Health Market Innovations. Bull World Health Organ. 2012 May 1;90(5):332-340.

78. Greenhalgh T, Procter R, Wherton J, Sugarhood P, Hinder S, Rouncefield M. What is quality in assisted living technology? The ARCHIE framework for effective telehealth and telecare services. BMC Med. 2015 Apr 23;13:91.

79. Mair FS, May C, O’Donnell C, Finch T, Sullivan F, Murray E. Factors that promote or inhibit the implementation of e-health systems: an explanatory systematic review. Bull World Health Organ. 2012 May 1;90(5):357-364.

80. De La Salud OP. Bases Metodológicas Para Evaluar La Viabilidad Y El Impacto De Proyectos De Telemedicina (spanish Edition). 2001st ed. Pan American Health Organization; 2001.

81. Collins A, Burns CL, Ward EC, Comans T, Blake C, Kenny L, et al. Home-based telehealth service for swallowing and nutrition management following head and neck cancer treatment. J Telemed Telecare. 2017 Dec;23(10):866-872.

82. Gehring K, Kloek CJ, Aaronson NK, Janssen KW, Jones LW, Sitskoorn MM, et al. Feasibility of a home-based exercise intervention with remote guidance for patients with stable grade II and III gliomas: a pilot randomized controlled trial. Clin Rehabil. 2018 Mar;32(3):352-366. 
83. Albergoni A, Hettinga FJ, La Torre A, Bonato M, Sartor F. The Role of Technology in Adherence to Physical Activity Programs in Patients with Chronic Diseases Experiencing Fatigue: a Systematic Review. Sports Med Open. 2019 Sep 12;5(1):41.

84. Galiano-Castillo N, Ariza-García A, Cantarero-Villanueva I, Fernández-Lao C, Díaz-Rodríguez L, Legerén-Alvarez M, et al. Telehealth system (e-CUIDATE) to improve quality of life in breast cancer survivors: rationale and study protocol for a randomized clinical trial. Trials. 2013 Jun $22 ; 14: 187$.

85. Cartmill B, Wall LR, Ward EC, Hill AJ, Porceddu SV. Computer literacy and health locus of control as determinants for readiness and acceptability of telepractice in a head and neck cancer population. Int $\mathrm{J}$ Telerehabil. 2016 Dec 15;8(2):49-60.

86. Timmerman JG, Tönis TM, Dekker-van Weering MGH, Stuiver MM, Wouters MWJM, van Harten WH, et al. Co-creation of an ICT-supported cancer rehabilitation application for resected lung cancer survivors: design and evaluation. BMC Health Serv Res. 2016 Apr 27;16:155. 